\title{
PRODUKTIVITAS DAN PENDAPATAN USAHA TANI UBI KAYU (MANIHOT UTILISIMA) DI DESA TUNGKARAN KABUPATEN BANJAR
}

\author{
(Productivity And Income Of Farming Cassava In Tungkaran Village Banjar Regency)
}

\author{
Fenny Refiana, Eddy Triatmoko, Subhan fitriadi \\ Fakultas Pertanian Universitas Achmad Yani Banjarmasin \\ Penulis koresponden : fennyrefiana@gmail.com
}

Article Submitted: 26-02-2021

Article Accepted: 21-05-2021

\begin{abstract}
The purpose of this study was to determine the revenue, explicit cost, income, and productivity of the cassava Sulawesi variety. This study was conducted from March to May 2021 at Tungkaran village Banjar regency. The simple random sampling method was used by observing 21 farmers in Tungkaran village who planted cassava. The productivity is $14,43 \mathrm{Ton} / \mathrm{Ha}$, the average explicit cost is Rp. 961.413,50/farmer, the average revenue is Rp. 2.468.142,86/farmer, and the average income Rp. 1.506.729,36/farmer. With the results of the development of the Sulawesi cassava variety, we certainly have good prospects and revenue of the average income, technical and economically.
\end{abstract}

Keywords: Revenue, cassava, explicit cost,income.productivity

\section{PENDAHULUAN}

Menurut Moehar (2001) usahatani adalah kegiatan mengatur atau mengelola aset di bidang pertanian. Usahatani juga bisa diartikan sebagai kegiatan yang menyelenggarakan fasilitas dan teknologi produksi pertanian di suatu perusahaan yang berkaitan dengan sektor pertanian.

Ubi kayu atau singkong tentunya sudah tidak asing lagi di masyarakat Indonesia, karena nama singkong atau ubi kayu sangat populer di banyak tempat sebagai makanan sehari-hari. Seringkali bahan makanan ini dikaitkan dengan taraf sosial seseorang, padahal ubi kayu enak sebagai bahan makanan sehari-hari. Ubi kayu merupakan produk pertanian yang tersebar luas di Indonesia dan merupakan sumber karbohidrat penting setelah nasi dengan kandungan karbohidrat 34,7\%. Namun kenyataannya, ubi kayu kurang dimanfaatkan. Oleh karena itu diperlukan pemanfaatan ubi kayu agar dapat menjadi bahan pangan yang bergizi tinggi. Ubi kayu dapat disajikan sebagai makanan pokok menggantikan nasi (jawa = tiwul), roti, tape, gatot, biskuit, pati dan berbagai makanan lainnya (Soetanto, 2001).

Ubi kayu juga merupakan salah satu tanaman pangan masa depan yang potensial karena mengandung karbohidrat sehingga dapat digunakan sebagai alternatif bahan pangan pokok. Ubi kayu tidak hanya mengandung karbohidrat, tetapi juga unsur lain: air sekitar 60\%, pati 25-35\%, serta protein, mineral, serat kalsium dan fosfat (Elfandari, 2008).

Strategi peningkatan produksi ubi kayu adalah dengan menanam stek batang ubi kayu 
dengan kualitas terbaik dengan potensi hasil tinggi, kandungan bahan kering tinggi, dan kandungan pati tinggi (Sundari, 2010). Selain penanaman bibit batang ubi kayu kualitas terbaik, perlakuan khusus juga bisa dilakukan untuk membantu keberhasilan penanaman dengan perbanyakan stek. Keberhasilan perbanyakan dengan stek ditunjukkan dengan regenerasi akar dan pucuk pada bahan stek sehingga menjadi tanaman baru. Faktor internal yang mempengaruhi terjadinya regenerasi akar adalah fitohormon yang berperan sebagai zat pengatur tumbuh (Elfandari, 2008).

Ubi kayu dianggap tanaman yang mudah beradaptasi dan tumbuh di beberapa iklim pertanian tropis yang tidak membutuhkan iklim tertentu untuk pertumbuhannya. Selain itu, ubi kayu dianggap sebagai tanaman yang menguruskan tanah, karena pemborosan dalam pengambilan unsur hara dan tidak mampu melindungi tanah dari air hujan serta membuat lahan ubi kayu menjadi rentan terhadap erosi (Salim, 2011).

Di Indonesia, ubi kayu merupakan tanaman pangan yang penting dan menempati urutan ketiga setelah padi dan jagung. Selain itu ubi kayu juga memiliki arti ekonomi terpenting dibandingkan dengan jenis umbiumbian yang lain (Chalil, 2003). Ubi kayu juga telah banyak dimanfaatkan dunia industri sebagai bahan baku bioethanol, tepung tapioka, sorbitol, gula cair dan monosodium glutamat (Yuliawati, 2009).

Menurut Mubyarto

produktivitas adalah perbandingan antara hasil produksi yang diperoleh dari suatu kesatuan input dengan kemampuan lahan.

Ada beberapa faktor yang dapat mempengaruhi suatu produktivitas yaitu: infrastruktur, modal, teknologi, kualitas bibit, pupuk dan pengetahuan atau tingkat pendidikan petani. Selain faktor-faktor yang disebutkan diatas, praktek manajemen dari suatu pemupukan dan lain sebagainya juga sangat mempengaruhi suatu produktivitas (Suparmi, 1986).

Pendapatan adalah selisih antara penerimaan dengan biaya eksplisit total (biaya nyata dikeluarkan). Pendapatan yang diperoleh seorang petani adalah imbalan yang diperoleh keluarga petani dari penggunaan faktor produksi, tenaga kerja dan modal yang diinvestasikan kedalam bidang usaha (Syarifuddin A. Kasim, 1995).

Desa Tungkaran Kecamatan Martapura merupakan salah satu desa di Kabupaten Banjar yang sebagian dari masyarakatnya bekerja sebagai petani dengan mata pencaharian usahatani ubi kayu. Adapun permasalahan yang dihadapi para petani ubi kayu diantaranya adalah masih minimnya modal yang dimiliki petani sehingga dalam pemanfaatan sarana produksi belum maksimal dan berfluktuasi terhadap harga komoditi ubi kayu.

Mengingat komoditi ubi kayu cukup banyak diusahakan di desa ini, maka peneliti dapat mengamati serta melihat keberadaan dari kegiatan usahatani ini. Baik dilihat dari segi teknis maupun dari segi ekonomis. Sehingga dalam pelaksanaannya nanti akan terlihat sejauh mana kegiatan usahatani ubi kayu ini dapat memberikan gambaran tentang produktivitas, biaya, penerimaan dan pendapatan petani.

\section{METODE PENELITIAN}

\section{Lokasi dan Waktu}

Lokasi dilaksanakannya penelitian ini yaitu di Desa Tungkaran, Kecamatan Martapura, Kabupaten Banjar. Dan waktu penelitian yaitu dari bulan Maret 2021 hingga bulan Mei 2021.

\section{Teknik Pengambilan Contoh}

Pengamatan ini menggunakan metode survey dengan teknik observasi, untuk menentukan jumlah responden contoh yang 
mengusahakan tanaman ubi kayu, dilakukan penarikan contoh dengan menggunakan teknik acak sederhana (simple random sampling). Dengan metode ini setiap petani akan mempunyai peluang yang sama (homogen) untuk dapat diambil sebagai contoh atau sampel.

Besarnya contoh yang diambil untuk bisa mendapatkan data yang refresentatif yaitu minimal $10 \%$ dari keseluruhan data yang ada (Masri Singarimbun, 1985). Di Desa Tungkaran Kecamatan Martapura Kabupaten Banjar jumlah petani yang menjalankan usahatani ubi kayu yaitu sebanyak 30 orang. Dari data ini kemudian dilakukan pengambilan sampel sebanyak $70 \%$ dari jumlah petani tersebut, sehingga diperoleh 21 orang petani responden.

\section{Analisis Data}

Dari data responden yang telah diperoleh tersebut, dianalisis dengan cara tabulasi dengan analisis finansial terkait biaya, penerimaan dan pendapatan usahatani tanaman ubi kayu petani responden tersebut.

Menurut Syarifuddin A. Kasim (1995) biaya eksplisit adalah biaya yang nyata dikeluarkan, dan untuk mengetahui besarnya biaya yang dikeluarkan oleh petani, dapat dirumuskan sebagai berikut:

$$
\begin{aligned}
& \text { TEC }=\sum_{i=1}^{n} \mathrm{EC}(i \\
& =1,2,3, \ldots, n) . .
\end{aligned}
$$

Keterangan

$\mathrm{TEC}=$ Total Explicit Cost / Biaya Eksplisit Total (Rp)

EC $(i=1,2,3 \ldots \ldots ., n)=$ Komponen Biaya

Eksplisit

\footnotetext{
Menurut Syarifuddin A. Kasim (1995) untuk mengetahui penerimaan secara matematis dapat ditulis sebagai berikut :
}

$\mathbf{T R}=\mathbf{P} \mathbf{X} \mathbf{Q}$

Keterangan

$\mathrm{TR}=$ Total Revenue $/$ Penerimaan Total $(\mathrm{Rp})$

$\mathrm{P} \quad=$ Price / Harga $(\mathrm{Rp} / \mathrm{Kg})$

$\mathrm{Q}=$ Quantity / Produksi $(\mathrm{Kg})$

Menurut Syarifuddin A. Kasim, (1995), untuk mengetahui pendapatan digunakan rumus sebagai berikut :

I $=$ TR - TEC

Keterangan

$\mathrm{I} \quad=$ Income / Pendapatan (Rp)

$\mathrm{TR}=$ Total Revenue / Penerimaan Total $(\mathrm{Rp})$

TEC $=$ Total Explicit Cost / Biaya Eksplisit

Total (Rp)

Adapun produktivitas lahan ubi kayu dapat diketahui dengan menggunakan persamaan perbandingan rata-rata produksi (Ton) dengan rata-rata luas lahan (ha) (Anggraeni,dkk, 2015).

Produktivitas $(\mathrm{Ton} / \mathrm{ha})=$ rata-rata produksi (Ton) / rata-rata luas lahan (ha)

\section{HASIL DAN PEMBAHASAN}

\section{Aspek Teknis Usahatani Ubi Kayu Pembersihan Lahan}

Pertama-tama dalam melakukan teknis budidaya ialah sanitasi lahan atau biasa disebut dengan pembersihan lahan tanam. Pada tahap ini dilakukan untuk membasmi tumbuhan inang hama atau penyakit yang kemungkinan akan datang. Petani di Desa Tungkaran ini menggunakan pengaplikasian herbisida dengan cara menyemprotkan ke arah gulma-gulma tersebut menggunakan sprayer sehingga gulma-gulma tersebut mati dan berubah warna menguning. Rata-rata luas areal tanam petani Desa Tungkaran 0,057 Ha.

\section{Pengolahan Tanah}

Proses olah lahan ini dimaksudkan agar struktur media tumbuh menjadi lebih remah sehingga pori-pori tanah terbuka memudahkan perakaran masuk ke dalam tanah, serta menekan pertumbuhan gulma agar tidak ikut bersaing dengan calon bakal 
tumbuhan ubi kayu. Para petani di Desa Tungkaran saat ini masih menggunakan cangkul sebagai media pengolahan tanah. Setelah tanah menjadi lebih gembur, saatnya menaburkan pupuk kandang ayam pada lahan tersebut rata rata 16,14 karung (1 karung setara $25 \mathrm{~kg}$ ).

\section{Penyiapan Stek Batang}

Bahan tanaman didapatkan dari bahan berupa batang ubi kayu terdahulu yang banyak dijual. Batang tanaman yang digunakan pada bagian pertengahan dan yang terpenting batang stek tersebut tidak ditumbuhi tunas baru serta permukaan yang lurus. Para petani di Desa Tungkaran tidak memiliki perlakuan khusus pada stek yang akan mereka tanam nantinya, mereka langsung menanam ke lahan yang telah siap ditanami. Mereka menggunakan jenis Ubi Kayu Kuning Sulawesi dalam penanaman usahatani ini. Rata-rata bibit diperlukan sebanyak 848,2 bibit ubi kayu per petani.

\section{Penanaman}

Waktu penanaman terbaik yaitu saat memasuki permulaan musim penghujan sehingga pertumbuhan lebih cepat. Disini petani di Desa Tungkaran menanam secara vertikal dengan jarak penanaman sekitar $70 \times 100 \mathrm{~cm}$, waktu terbai tanam di bulan Nopember-Desember hingga panen diperkirakan bulan Mei-Juni setelah itu baru kita buat lubang untuk memasukkan pupuk Phonska di dekat lubang tanam stek. Jika sudah tutup kembali lubang tersebut lalu taburkan Furadan $3 \mathrm{gr}$ di sekitar lubang tanam agar stek tidak dimakan oleh hama. Rata-rata yang digunakan sebanyak 1,24 Kg.

\section{Pemeliharaan}

Dalam teknik budidaya ubi kayu ini, persoalan pemeliharaan ialah hal yang bisa dibilang amat mudah, kita hanya perlu melakukan penyulaman, pembumbunan serta penyemprotan (Gramoxone) gulma saja.
Untuk masalah penyiraman, tanaman ubi kayu bergantung sekali dengan keadaan alam yakni menunggu datangnya turun hujan.

\section{Panen dan Produksi}

Ciri tanaman ubi kayu yang dapat dipanen yaitu daun bagian bawah berkurang tumbuhnya, daun menjadi kuning dan berguguran. Dapat dilakukan pada umur 7-8 bulan dihitung sejak tanam. Cara panen ubi kayu dengan menarik batang tanaman dan umbinya dilepas. Ciri ubi kayu jenis Kuning Sulawesi ini yakni tidak terlalu panjang, padat berisi serta pada bagian dalam memiliki warna kuning. Total keseluruhan panen $17.277,00 \mathrm{~kg}$ atau rata-rata $822,71 /$ petani. Pengambilan hasil yang baik dan benar akan mendapatkan umbi yang berkualitas sehingga dapat meningkatkan penghasilan ubi kayu (Nuni Anggraini, dkk. 2017).

\section{Aspek Ekonomis Usahatani Ubi Kayu}

Unsur biaya yang diperhitungkan dan ditelaah pada usaha ubi kayu pada periode 1 (satu) kali musim tanam yaitu 7 (tujuh) bulan, meliputi pembiayaan komponen proses produksi, peralatan perlengkapan, pajak lahan serta upah kerja.

\section{Biaya Susut Peralatan}

Biaya susut alat perlu diperhitungkan karena setiap peralatan usahatani tentunya akan mengalami pengurangan nilai kekuatan alat itu sendiri yang dihitung berdasarkan biaya awal pembelian, umur penggunaan, nilai sisa dan waktu efektif penggunaan alat ubi kayu rata rata biaya penyusutan alat seperti cangkul Rp. 2.158,73, parang Rp. 825,40 dan handsprayer Rp. 7.083,33.

\section{Biaya Terhadap Upah Kerja di Luar Keluarga}

Pada usahatani ubi kayu yang diselenggarakan satu periode tanam, upah kerja di luar keluarga yang mencakup pembuatan lahan rata -rata Rp. 230.952,38/petani, penanaman Rp. 
68.333,33/petani dan panen Rp. 68.571,43/petani dengan total keseluruhan rata-rata $367.857,14 /$ petani, sedangkan pemeliharaan dilakukan tenaga kerja dalam keluarga.

\section{Pajak Lahan}

Pajak terhadap lahan disesuaikan dengan luasan dan kepemilikan serta periode tanam ubi kayu. Nilai pajak pada waktu penelitian berkisar Rp. 10.000,-/borong/tahun. Adapun besarnya nilai pajak rata-rata petani ubi kayu di Desa Tungkaran adalah Rp. 11.388,89,-/petani.

\section{Pembiayaan Komponen Proses Produksi}

Pembiayaan komponen proses produksi yang digunakan diperhitungkan dengan cara pengalian keseluruhan komponen produksi dengan harga satuan komponen. Pembiayaan mencakup harga bahan tanaman keperluan pemupukan, biaya rata-rata Furadan dan Gramoxone, upah kerja diluar keluarga (pengolahan lahan, penanaman, panen), pajak lahan, dan susut peralatan (cangkul, parang, handsprayer). Uraiannya dijelaskan pada Tabel 1.

Tabel 1. Biaya eksplisit usahatani ubi kayu Desa Tungkaran

\begin{tabular}{llcccr}
\hline No & \multicolumn{1}{c}{ Rincian } & Jumlah & Rerata/responden & Jumlah (Rp) & Rerata/responden \\
\hline 1 & Bibit & $17.811 \mathrm{bt}$ & 848,14 & 1.781 .100 & $84.814 .29,00$ \\
2 & Phonska & $402 \mathrm{~kg}$ & 19,40 & 4.020 .000 & $191.428,57$ \\
3 & Furadan & $26 \mathrm{~kg}$ & 1,24 & 780.000 & $37.142,86$ \\
4 & Gramoxone & $21 \mathrm{~kg}$ & 1,00 & 1.365 .000 & $65.000,00$ \\
5 & Pupuk Kandang & 339 karung & 16,14 & 4.068 .000 & $193.714,29$ \\
6 & TKLK & & & 7.725 .000 & $367.857,14$ \\
7 & Pajak Lahan & & 239.166 & $11.388,89$ \\
8 & Penyusutan Alat & & 211.416 & $10.067,46$ \\
\hline 9 & Total & & 20.189 .682 & $961.413,50$
\end{tabular}

Sumber : Pengolahan Data 2021

\section{Penerimaan}

Penerimaan yakni pengalian seluruh hasil produk atas nilai jual produk ketika penelitian sebesar Rp 3000/Kg, dari hasil wawancara dengan seluruh petani responden diperoleh total rata-rata produksinya adalah sebesar 822,71 kg/petani. Sedangkan total penerimaan rata-rata adalah $\mathrm{Rp}$. 2.468.142,86.-/petani. Penerimaan dapat ditingkatkan dengan besarnya produksi dan jaminan harga jual yang tinggi akan berpengaruh besar pada penerimaan dan pendapatan . Semakin besar produksi dan semakin tinggi nilai penjualan akan memperbesar pendapatan usahatani ubi kayu (Rofiatul Muizah,dkk. 2013). 
Tabel 2. Rerata produksi dan penerimaan usahatani ubi kayu Desa Tungkaran

\begin{tabular}{lccc}
\hline No & Hasil Produk $(\mathrm{kg})$ & Nilai Jual $(\mathrm{Rp})$ & Penerimaan $(\mathrm{Rp})$ \\
\hline 1 & 822,71 & 3000 & $2.468 .142,86$ \\
\hline
\end{tabular}

Sumber : Pengolahan Data Primer 2021

\section{Pendapatan}

Pendapatan usaha ubi kayu yang dimaksud yakni total penerimaan dikurangkan dengan seluruh biaya yang nyata digunakan (explicit cost) pada satu periode usaha. Pendapatan usaha rata-rata diperoleh petani pada satu periode usaha ubi kayu Rp. 1.506.729,36,-/petani. Pendapatan masih dapat ditingkatkan dengan mempelajari situasi pasar dan sistem pemasaran agar memperoleh harga yang memadai. Agar tingkat pendapatan meningkat perlu adanya peningkatan peningkatan efesiensi biaya dan peningkatan penerimaan (TR) melalui peningkatan hasil produksi. Hal ini bisa dilaksanakan apabila petani mengetahui penggunaan hubungan antara input dan output. Semakin optimal penggunaan input produksi diharapkan output bisa lebih maksimal.

Banyaknya hasil yang terjual berpengaruh pada pendapatan, yang mana pendapatan makin tinggi seiring dengan peningkatan hasil (Adi Safruardi et al,2012). Pendapatan dapat ditingkatkan dengan upaya menekanan biaya-biaya produksi dan meningkatkan hasil produksi dengan perbaikan sistem teknologi ataupun luasan lahan.

Menurut I Nengah Mardika, dkk. (2017), upaya dalam peningkatan pendapatan sebaiknya petani menekan biaya produksi semaksimal mungkin dan berusaha meningkatan hasil produksi dalam berusahatani.

Tabel 3. Rerata pendapatan usahatani ubi kayu Desa Tungkaran

\begin{tabular}{llll}
\hline No & Penerimaan $(\mathrm{kg})$ & Biaya eksplisit $(\mathrm{Rp})$ & Pendapatan $(\mathrm{Rp})$ \\
\hline 1 & $2.468 .142,86$ & $961.413,50$ & $1.506 .729,36$ \\
\hline
\end{tabular}

\section{Produktivitas}

Kemampuan berproduksi sebuah lahan dalam satuan luas dan waktu musim tanam di Desa Tungkaran memang mampu menunjukkan angka yang masih belum baik dengan perbandingan wilayah lain di Kalimantan rata-rata produksi $822,71 \mathrm{~kg}$ $(0,823$ ton $)$ dan rata-rata luas lahan $566,19 \mathrm{~m} 2$ (0,057 Ha) maka produktivitas $14,434 \mathrm{Ton} / \mathrm{ha}$. Produktivitas ini memang masuk golongan rendah jika perbandingan rerata produktivitas pada Kabupaten Banjar Kalimantan Selatan sebesar 36,796 ton (Rendy Fadillah dkk,2018). Produktivitas bisa dikatakan rendah bisa disebabkan faktor karena luasan lahan masih kecil disebabkan hujan dan banjir yang cukup panjang melanda Desa Tungkaran dan juga teknologi pembudidayaan masih banyak yang sederhana, namun hal ini bisa diketahui karena produktivitas ini juga semestinya masih bisa ditingkatkan dengan perbaikan teknologi secara maksimal.

\section{KESIMPULAN DAN SARAN}

\section{Kesimpulan}

Dari hasil penelitian juga analisis data primer tentang usaha ubi kayu di Desa Tungkaran, maka dapatlah diambil kesimpulan yakni : 
1. Hasil produk yang didapatkan dari usaha ubi kayu di Desa Tungkaran dari 21 petani responden dengan rata-rata luas lahan 566,19 $\mathrm{m}^{2}$ menghasilkan hasil produksi rata-rata sebesar 822,71,$\mathrm{kg} /$ petani dengan produktivitas ubi kayu 14,43 Ton/ha.

2. Total pembiayaan sebesar Rp 20.189.682 atau rata-rata Rp. 961.413,50/petani.

3. Total Penerimaan petani responden sebesar Rp. 51.831.000 atau rata-rata Rp. 2.468.142,86.-/petani/musim tanam.

4. Total Pendapatan petani responden di Desa Tungkaran ialah sebesar Rp. 31.641.3 16,56 atau rata-rata $\mathrm{Rp}$. 1.506.729,36/petani.

\section{Saran}

Memperhatikan hasil penelitian serta bahasan penjelasan pada usaha ubi kayu di Desa Tungkaran, sehingga memunculkan saran yaitu :

1. Perlunya peningkatan keberhasilan usahatani tanaman ubi kayu di Desa Tungkaran dengan dilakukan perbaikan sumber daya manusia melalui peningkatan keterampilan petani, perbaikan penyelenggaraan usahatani, penyediaan sarana produksi dan penggunaannya yang sesuai anjuran, penggunaan tenaga kerja yang optimal melaui peningkatan kemampuan petani dalam penyelenggaraan usahatani tanaman ubi kayu memperluas areal tanaman.

2. Memberikan penyuluhan pertanian, pelatihan dan kursus intensif yang diperlukan untuk meningkatkan pendidikan dan kemampuan petani baik dalam teknis, budidaya maupun aspek manajemen.dan juga perlunya kajian penelitian lanjutan lebih terperinci.

\section{DAFTAR PUSTAKA}

Adi Safruwardi, Hairin Fajri, Hamdani, 2012. Analisis Finansial Usahatani Padi Varietas Unggul di Desa Guntung Ujung Kecamatan Gambut Kabupaten Banjar Kalimantan Selatan. Jurnal Agribisnis Perdesaan Volume 02 nomor 03 September 2012 hal 181192.

Chalil, D. 2003. Agribisnis Ubi kayu di Propinsi Sumatera Utara. Jurusan Sosial Ekonomi Pertanian, Fakultas Pertanian, Universitas Sumatera Utara. Medan.

Dyah Anggraeni J, Darsono, Mei Tri Sundari, 2015. Analisis Produktivitas lahan dan pendapatan usahatani padi di kawasan pesisir Kabupaten Purwarejo . Jurnal Agrista Vol 3 no 2 juni 2015 hal 97108. ISSN 2302-1713.

Elfandari, H. 2008. Pengaruh Pemberian Konsentrasi IBA dan Jumlah Stek Buku Terhadap Perakaran Stek Batang Mini Tanaman Ubi kayu (Manihot esculenta Crantz) Skripsi Universitas Lampung : Bandar Lampung.

I Nengah Mardika,I Ketut Rantau,Putu Udayani Wijayanti,2017.Aanalisis Usahatani Ubi kayu Varietas Gajah Desa Bukti Kecamatan Kubutamban Kabupaten Buleleng) E. Jurnal Agribisnis dan Agrowisata ISSN:2301-6523 Vol 6 no 2 April 2017.

Masri Singarimbun. 1985. Transmigrasi di Indonesia 1905 - 1985). Jakarta : Universitas Indonesia. 
Moehar, 2001. Pengantar Ekonomi Pertanian. Jakarta : Bumi Aksara.

Mubyarto, 1998. Pengantar Ekonomi Pertanian, Lembaga Penelitian Pendidikan dan Penerangan Ekonomi dan Sosial (LP3ES). Jakarta.

Nuni Anggaraeni, Haranto, Lukitawati Anggraeni, 2017. Analisis Pendapatan Dan Faktor Produksi Usahatani Ubi kayu Berdasarkan Pasar Yang dipilih Petani.Jurnal JOFSA vol 1,no 1 April 2017.PP 12-21 ISSN : 0000-0000.

Renndy Fadillah Akbar, Hairi Firmansyah, M.Hussaini, 2018. Analisis usahatani ubi kayu di Desa Cindai Alus Kecamatan Martapura Kota Kabupaten Banjar. Jurnal Frontier Agribisnis ULM Desember vol 3no (4),2019.
Rofiatul Muizah, Suprapti Supardi, Shofia Nur Awami. 2013. Analisis Pendapatan Usahatani Ubi kayu (Manihot esculenta crantz), Jurnal Ilmu-ilmu Pertanian Mediagro vol 9 no $22013.55-67$.

Syarifuddin A. Kasim, 1995. Petunjuk Praktis Menghitung Keuntungan Dan Pendapatan Usahatani. Fakultas Pertanian Unlam Banjarbaru.

Salikin, K.A. 2003. Sistem Pertanian Berkelanjutan. Yogyakarta : Kanisius.

Salim, E. 2011. Mengolah Singkong Menjadi Tepung Mocaf. Yogyakarta: Andi Offset.

Suparmi. 1986. Ekonomi Pertanian Karunika Jakarta Universitas Terbuka. Jakarta. 